DOI https://doi.org/10.18551/rjoas.2020-10.03

\title{
FINANCIAL DISTRESS ANALYSIS AT <XYZ>'S HOTEL IN INDONESIA
}

\author{
Achsani Noer Azam, Bandono Bayu, Miranti \\ School of Business, Bogor Agricultural University, Indonesia \\ *E-mail: sayamiranti@gmail.com
}

\begin{abstract}
The development of hotel operators in Indonesia, both conventional hotel operators and digital-based hotel operators (VHO) encourages the growth of the hotel operator business. One of the local players in the hospitality industry is $X Y Z$, with three subsidiaries hotels $(\mathrm{MHH}, \mathrm{SPH}$, and $\mathrm{BIH})$ which using hotel operator. During the last five years, there were several XYZ's hotels financial indicators that were not achieved with a downward trend in financial performance. This study is intended to see the impact of using hotel operator to financial distress risk using Altman Z-Score and Debt Service Coverage Ratio (DSCR). The result shows that $\mathrm{MHH}$ underwent financial distress in 2002 to 2006 and the following year was categorized as Health Company, as company profits improved. SPH during the study period was categorized as a health company. BIH was in financial distress from 2001 to 2006 and from 2017 to 2018 due to loans for renovations do not increase revenues and profits with negative retained earnings for the past 4 (four) years. This study is using actual performance data from three hotels belong to $X Y Z$ over multiple years to validate the effectiveness of hotel operator, where hotel operator does not always have an impact in the financial performance of the hotels.
\end{abstract}

\section{KEY WORDS}

Hotel management, hotel performance, financial performance, financial distress, hotel operator, Altman z-score, debt service coverage ratio.

Hospitality and tourism are some of the most promising economic sectors for long-term growth and contribute to world economic strength and social development (WTTC, 2019). The accommodation business in Indonesia can be broken down based on its accommodation management system. In 2018, most accommodation businesses have their own (independent) accommodation management system, which is 26612 businesses or $94.27 \%$. While the remaining 474 businesses or $1.68 \%$ has an international chain of the accommodation management system and as many as 1144 businesses or $4.05 \%$ have a national chain accommodation management system. When viewed by province, the province of Bali has the highest number of accommodation businesses, both accommodation businesses with international chain management systems, national chains, and independents.

In general, between hotel owners and hotel operators, a hotel management contract or agreement is specifically designed by both parties. Each party has reciprocal rights and obligations. Most disputes arise in the implementation of hotel management contracts due to differences in perception of the financial statements between the operators and the owner. However, some hotel owners broke management contracts because the agreed income targets were not reached and the costs for the hotel management were too large (Juliana 2003). From the perspective of the hotel operator, the difference between the hotel operator and other hotel operators can be seen from the brand, design, service standards, reservation system, and global logistical support (Kundu 1998). But if this difference cannot have an impact in the form of increasing financial performance for hotel owners, then hotel owners will soon realize that the investment spent on the use of hotel operators is not worth the increase in the value of their assets. In other words, hotel operators must increase efficiency in operations by increasing sales and or reducing costs (Yoo 1998).

One of the Indonesian local players in the hospitality industry is $X Y Z$, which was established in 1973. XYZ is a subsidiary of a State-Owned Enterprise that operates in the 
hospitality industry and has three hotels subsidiaries namely $\mathrm{MHH}, \mathrm{SPH}, \mathrm{BIH}$. Before 2010, $\mathrm{MHH}, \mathrm{SPH}$, and $\mathrm{BIH}$ were hotels under the management of $\mathrm{XYZ}$ as the parent company. Along with the development of business competition in the hospitality industry, $X Y Z$ determines the strategic direction of the company from operating holding to strategic holding. For this reason, $X Y Z$ no longer carries out business operations and using hotel operator. Compared to competitors in the hotel industry, $X Y Z$ 's hotels have a declining income and net profit after tax performance, while competitors show a revenue growth of $17.0 \%$ and net profit after tax of $485.0 \%$. This shows that the three $X Y Z$ hotels did not achieve performance in line with industry trends. The hotel industry data was obtained from data from publicly listed companies engaged in the hotel industry in Indonesia. The important role of hotel operators for hotel owners both $X Y Z$ and third parties will have an impact on hotel business performance. Based on AHH's policy as an XYZ hotel operator, this study tries to look at the effect of using a hotel operator, whether it will further increase or even reduce the financial performance of $X Y Z$ hotels so that they tend to face financial distress risk.

\section{LITERATURE REVIEW}

Hotel Operators. Hua (2017) discuss the relationship costs incurred for operators with the level of Revenue per Room Availability (RevPAR) generated. Research shows how using hotel operators adds value to a hotel and has an interest in hotel performance (O'Neill and Carlback 2011) and that is the power of brands and creating brands that generate positive profits for businesses (Damonte 1997). Added value can be given from shared resources from hotel operators that provide benefits from economies of scale, better cost management, customer loyalty programs, and more effective expenditure management. Lower tariff compared to international network operators. Challenges that must be questioned by hotel operators and independent hotel owners in Indonesia. Hotel owners who use international networks are usually local investors but do not have sufficient hotel and network management skills to choose to be managed by international network operators (Nikolskaya 2017).

Sheresheva (2018) examined the international hotel operator network in Russia with the results of the study showing that international hotel operator networks can use their core competencies in the hospitality business and its global network to develop the hotels they manage. The strategy of international hotel chains in Russia is different from local hotel chains, where local hotel chains prefer to buy hotel assets, while international hotel chains manage hotels. Russian local hotel chains are focused on two or three-star hotels, while international hotel chains operate in four or five-star hotels.

Financial Distress. Andrade and Kaplan (2002), the company will experience financial distress if the company cannot fulfill its debt repayment to all parties, whether banks, suppliers, or other third parties. Research conducted by Gilson (1990) introduces financial distress measurement in terms of past performance returns from stock in the last three years. Pranowo (2010) mentions financial indicators that influence companies to experience financial distress is the efficiency that is measured through the ratio between earnings before interest, tax, depreciation, and amortization with total assets, leverage measured by the ratio between the matured debt and the available funds, equity measured by total company capital in bookkeeping, and current ratio measured by comparison between current assets and current liabilities. Some models that predict financial distress that will be used in this study are the Altman Z Score for non-manufacturing companies (Z'- score) and the value of DSC (Debt Service Coverage).

Altman Z Score Model for non-manufacturing companies (Z '- score):

$$
Z=6.56 \times 1+3.26 \times 2+6.72 \times 3+1.05 X 4
$$

Where: $\mathrm{X} 1=$ Working Capital / Total Assets; X2 = Retained Earnings / Total Assets; X3 = Earnings Before Interest / Total Assets; X4 = Book Value of Equity / Book Value of Total Liabilities. With the following evaluation criteria: 
- $Z$ " - Score $<1.10$ is categorized as a company that has very large financial difficulties and high risk so that the possibility of bankruptcy is very large;

- $\quad 1.10<Z$ " - Score $>2.60$ is in the gray area so that it is categorized as a company that has financial difficulties, but the possibility of being saved and the possibility of bankruptcy is equally dependent on the policy decisions of the company's management as the decision-maker;

- Z " - Score> 2.60 is categorized as a very healthy company so that it does not experience financial difficulties.

Debt Service Coverage Ratio (DSC):

$$
\text { DSC }=(\text { total net income }) \div \text { total debt service }(2)
$$

Total net income is calculated by EBITDA value minus tax value and total debt service are calculated by calculating all principal installments with interest costs and coupon bonds owned.

\section{METHODS OF RESEARCH}

The data source is derived from the audited financial statements of each $\mathrm{XYZ}$ hotel as of December 31 during the period 2001-2018. Other data used in this study were taken from several sites, including the official Central Bureau of Statistics.

The test variable is the financial distress risk based on Working Capital, Total Asset, Retained Earnings, Earnings Before Interest, Book Value of Equity, Book Value of Total Liabilities, Earning Before Interest, Tax, and Depreciation, Interest Cost.

\section{RESULTS OF STUDY}

$\mathrm{MHH}$ is one of $\mathrm{XYZ}$ 's hotel located at Sanur, Bali. MHH entered into a management services agreement by using a hotel operator since January 1, 2010. During the period 2001 to 2006, MHH income showed a declining trend due to the Bali Bombing Events, which resulted in a decrease in the number of tourists to Bali. Along with the improving security situation in Indonesia that is increasingly conducive, the level of tourist visits to Indonesia has again increased and this has had an impact on increasing $\mathrm{MHH}$ revenues in the period after 2006 to 2018.

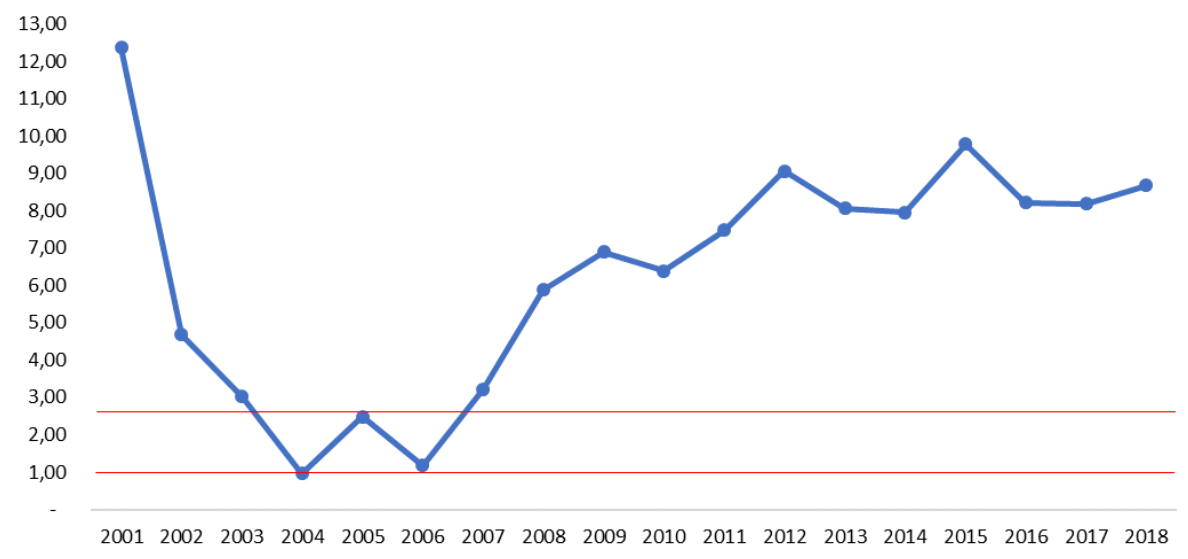

Figure 1 - Z-Score MHH 2001-2018

MHH financial distress risk by using Altman Z-Score analysis as shown in Figure 1 and Debt Service Coverage Ratio (DSC) value as shown in Figure 2. Based on the Z-Score value in Figure 1, MHH has potential bankruptcy in 2004 with a Z-Score of 0.95 . This is in line with the increase in losses after tax in the period 2002 to 2004 due to unstable security conditions 
in Bali. Also, the existence of bank loans used for the renovation of hotel buildings resulted in a decrease in Z-Score in 2003 and 2004.

In 2005, the Z-Score improved to the gray area due to a decrease in losses and an increase in cash equivalents due to improved room occupancy rates. The improvement of the Z-Score did not last long because in 2005 also a second Bali bombing occurred which resulted in $\mathrm{MHH}$ performance in 2006 again declining so that the Z-Score value in 2006 also declined. Along with the improving security conditions in Bali, tourists return to Bali so that $\mathrm{MHH}$ performance improves as well and the Z-Score in the period 2008 to 2018 is in a healthy condition. Withdrawal of the biggest dividend on $\mathrm{MHH}$ that occurred in 2014 resulted in a decrease in the Z-Score of $\mathrm{MHH}$ in that year. The value of working capital, EBIT, and positive maintained equity from 2007 to 2018 shows that $\mathrm{MHH}$ is in a healthy condition.

DSC MHH value as shown in figure 2 shows that from 2002 to $2006 \mathrm{MHH}$ was predicted to experience financial distress. This is in line with the $\mathrm{MHH}$ solvency value which has been increasing from 2002 to 2008. The increase in insolvency is due to a bank loan in 2002 that has a period of 5 (five) years and is due in 2008. The loan is used to finance building renovations, operational financing, and purchasing $\mathrm{MHH}$ equipment. This condition was aggravated by negative net profit conditions so that $\mathrm{MHH}$ was unable to cover existing debts in the period 2002 to 2004.

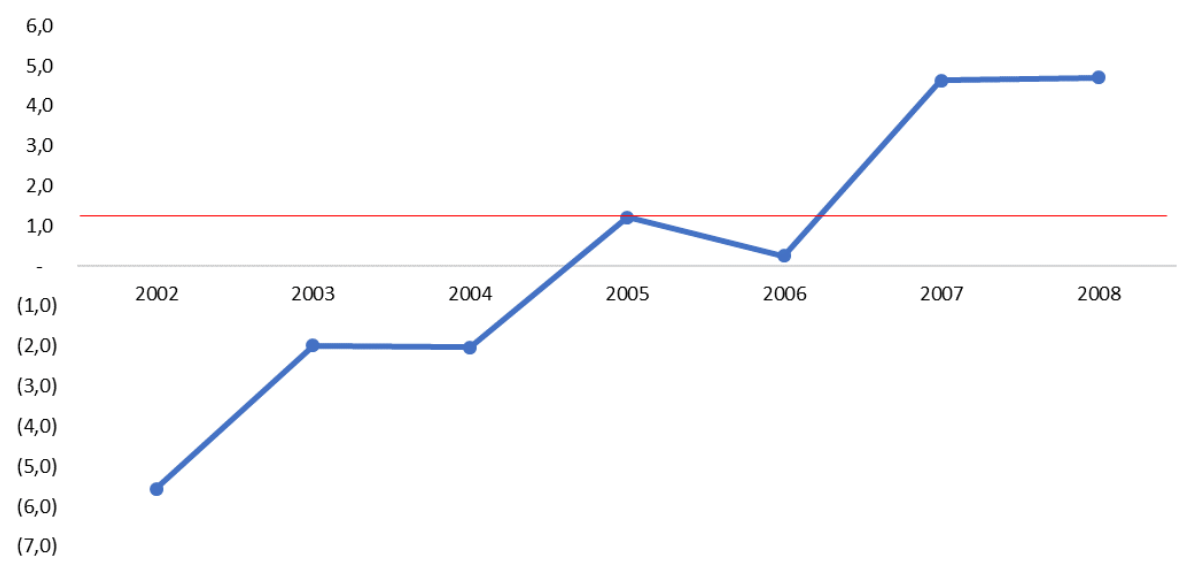

Figure 2 - DSC MHH 2001-2018

The Bali Bombing II incident also affected the MHC DSC ratio, which in 2005 had a DSC value of 1.2. The increase in profits in 2007 and 2008 helped increase the DSC MHH ratio so that it was able to get out of financial distress. In the study period of 2009 to 2018 , $\mathrm{MHH}$ did not have long-term loans that were due and interest expense so the value of the DSC ratio could not be calculated.

$\mathrm{SPH}$ is located at Senggigi, Nusa Tenggara Barat of Indonesia. SPH entered into a management services agreement by using a hotel operator since January 1, 2010. During 2001-2006, SPH's operating income showed a declining trend due to security and political conditions in Indonesia due to the riots in Lombok and acts of terrorism in Bali which affected the number of guests, especially foreign tourists, to the Lombok area. From 2006 to 2018 there was an increase in income. In terms of costs, along with the increase in revenue, SPH shows a trend of increasing costs both in terms of basic costs, operating costs, and other operating costs. The highest profit after tax was achieved by SPH in 2016 amounting to Rp5.4 billion with a Net Profit Margin ratio of $10 \%$. This condition did not proceed sustainably because in 2018 SPH recorded a trend of Net Profit Margin which declined from 6\% in 2017 and to $4 \%$ in 2018 due to increased SPH operating costs.

Debt to Equity Ratio before 2003 was above 20\% due to debts owed to contractors working for the construction of the Pool Villa Club. During the study period, SPH did not have a loan to a bank so that the SPH DER value was maintained in the range of $7 \%-25 \%$. In $2016 \mathrm{SPH}$ recorded an increase in long-term liabilities due to an increase in post- 
employment benefit liabilities and company service tenure awards. The increase in long-term liabilities resulted in Debt to Equity and Debt to Total Assets of SPH to increase from 2016 to 2018.

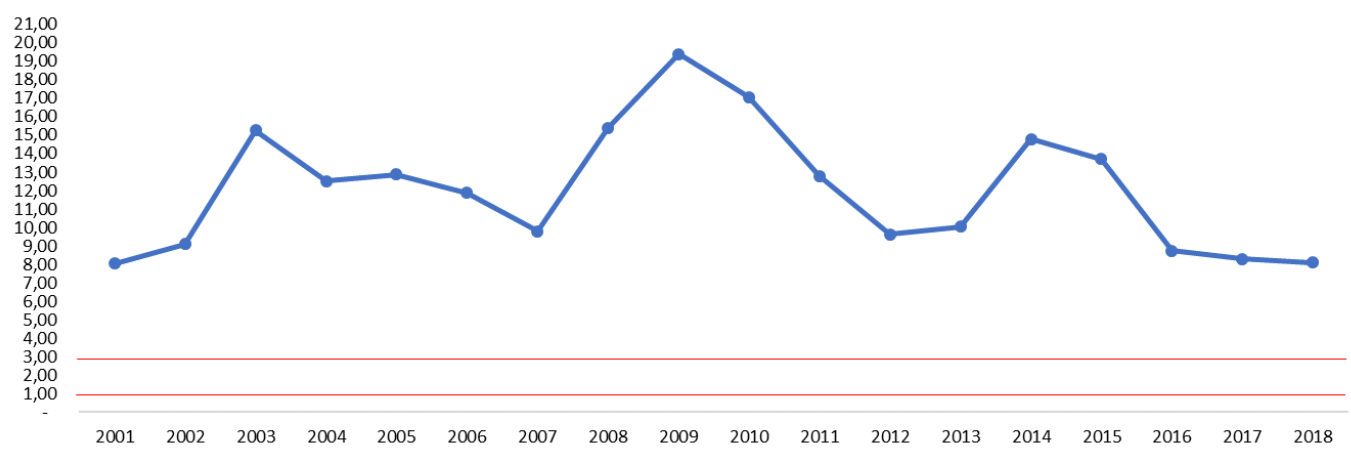

Figure 3 - Z-Score SPH 2001-2018

Based on the Z-Score value, SPH was in a healthy condition during the study period, namely 2001 to 2018. The value of working capital, retained earnings, equity, and EBIT SPH was maintained positively from 2001 to 2018 so that the SPH Z-Score showed that the SPH is in a healthy company condition. During the study period, SPH did not have long-term loans that were due and interest expense, so the DSC ratio assessment could not be carried out at $\mathrm{SPH}$.

$\mathrm{BIH}$ is located at Bandung, West Java, Indonesia. BIH also entered into a management services agreement by using a hotel operator since January 1, 2010. From 2001 to $2007 \mathrm{BIH}$ recorded a negative equity value. The equity condition in 2008 improved due to the revaluation of assets by measuring the fixed assets of land and buildings. In $2008 \mathrm{BIH}$ recorded a revaluation surplus of Rp38.1 billion so that the value of equity increased to Rp41.8 billion. From 2007 to $2011 \mathrm{BIH}$ recorded an average profit of IDR 5 billion per year. This increased the value of BIH's equity and caused the Return on Equity of BIH to be quite good in that period. However, from 2012 to 2018, BIH's financial performance in terms of profit after tax showed a declining trend and even suffered losses due to increasingly fierce competition in hotels in the Bandung area.

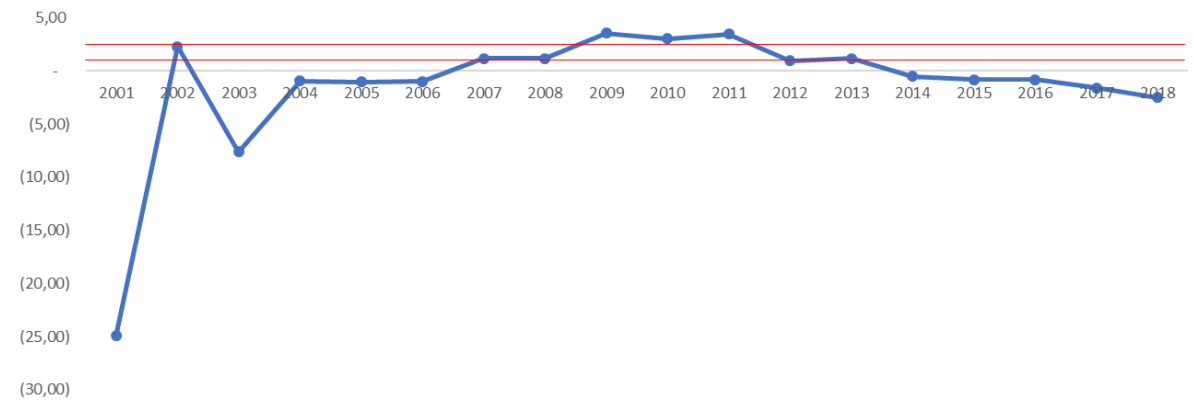

Figure 4 - Z-Score BIH 2001-2018

Before 2010 the value of the Current Ratio and Net Working Capital to Total Assets was higher than after 2010 due to $\mathrm{BIH}$ doing renovations in 2012. These renovations resulted in an increase in the value of debt to third parties and in 2018 an increase in income received in advance resulting in increased liabilities smoothly. As of 2018, the value of BIH Current Ratio is $51.0 \%$, meaning that $\mathrm{BIH}$ has the ability of $51.0 \%$ to pay its current liabilities using current assets.

$\mathrm{BIH}$ from 2001 to 2007 recorded a negative equity value due to losses due to loan interest expenses borne from the previous period. This resulted in BIH's Debt to Equity Ratio (DER) recorded negative. BIH has a high enough risk due to the debt composition of 6.8 
times compared to its own capital. These conditions made it difficult for BIH to obtain debt from outside parties to develop business. Bank loans made in 2012 for renovations have not been able to provide leverage for the increase in BIH revenues in subsequent years.

$\mathrm{BIH}$ in 2001 experienced the lowest Z-Score due to the high total loans used for renovations. In line with the credit restructuring in 2002, the BIH Z-Score increased to 2.32. However, due to the high value of accumulated losses recorded in BIH's equity from 2002 to 2007 , the value of Z-Score of BIH in that period had the potential for bankruptcy. In line with the revaluation of assets and positive profits, the value of the BIH Z-Score improved in 2008 and was categorized as healthy in the period 2009 to 2011. In $2012 \mathrm{BIH}$ again made longterm loans to renovate the building, resulting in the value of the BI-Z-Score showing a trend that is decreased until 2018. This was exacerbated by the negative performance of BIH profitability in the period 2013 to 2018 which can be seen in figure 14 . The interest expense increase in post-retirement benefit obligations and corporate service awards resulted in the value of the BIH Z-Score entering into the potential for bankruptcy from 2014 to 2018. This is supported by the value of BIH's equity which has been increasingly eroded to the level of Rp4.6 billion in 2018.

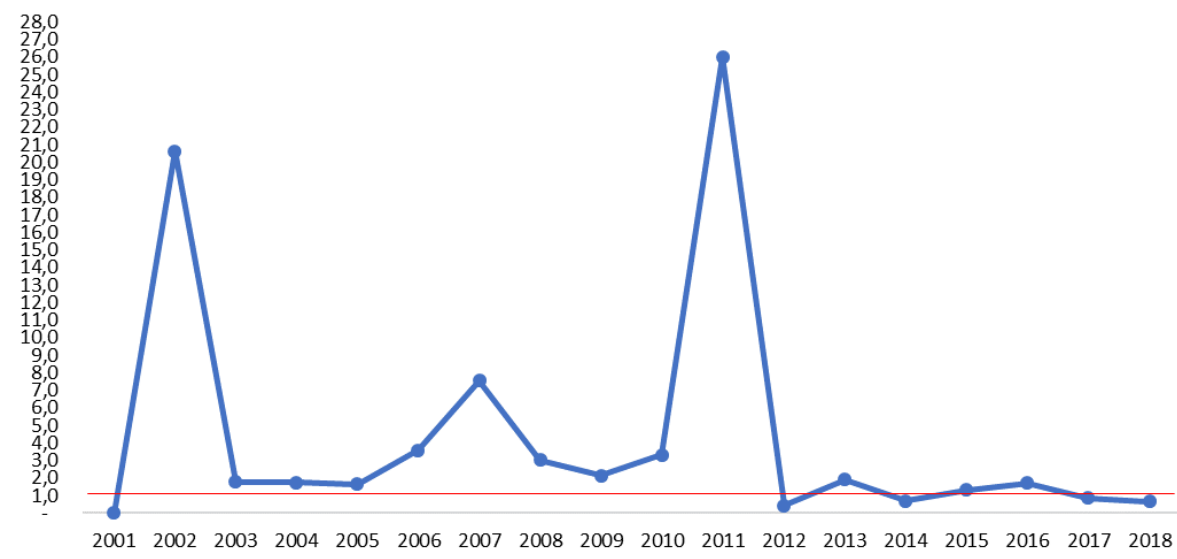

Figure 5 - DSC BIH 2001-2018

The BIH DSC value as shown in Figure 5 shows that in 2012, 2014, 2017, and 2018 $\mathrm{BIH}$ is predicted to experience financial distress. This is due to a loan in 2012 that is due in 2021. The loan is used to finance the renovation of buildings, and operational financing for $\mathrm{BIH}$. BIH's working capital in the period after making loans in 2012 showed negative, meaning that BIH's current liabilities were higher than current assets so that they were unable to cover current liability payments. The condition of the decreasing ratio of BIH DSC in 2012, 2014, 2017, and 2018 was also due to a significant decrease in net income of BIH in 2017 and 2018.

\section{CONCLUSION}

The financial distress test at $\mathrm{MHH}$ shows that $\mathrm{MHH}$ experienced financial distress from 2002 to 2006 due to the Bali bombings and bank loans. For the financial distress test at SPH, $\mathrm{SPH}$ is still considered healthy because the value of working capital, retained earnings, equity, and EBIT are maintained positively throughout the study period. Based on the financial distress test, it appears that BIH tends to be in financial distress in 2017 and 2018 due to negative retained earnings for the past 4 (four) years.

To be able to get out of financial distress, BIH must pay attention to and control financial variables, such as Profit, Efficiency, Leverage so that the financial status in a financial distress condition does not continue to deteriorate towards bankruptcy, but can rise again as a healthy company (emergence financial distress). 


\section{REFERENCES}

1. [WTTC] World Travel and Tourism Council. 2019. Travel and tourism economic impact 2019 [internet]. [2019 September 07]. https://www.wttc.org//media/files/reports/economic-impact-research/regions-2019/world2019.pdf.

2. Juliana I, Pramono N. 2003. Telaah kontrak manajemen hotel jaringan internasional antara pihak pemilik dan pihak pengelola hotel menurut peraturan kepariwisataan di Bali [tesis]. Yogyakarta (ID): Universitas Gadjah Mada.

3. Contractor FJ., Kundu SK. 1998. Franchising versus company-run operations: modal choice in the global hotel sector. Journal of International Marketing. 6(2):28-53.

4. Yoo B, Donthu N, Pilling PK. 1998. Channel efficiency: franchise vs non-franchise systems. Journal of Marketing Channels. 6(3):1-15.

5. Hua N, O'Neill JW, Nusair K, Singh D. 2017. Does paying higher franchise fees command higher RevPAR? International Journal of Contemporary Hospitality Management. 29(11):2941-2961.

6. O'Neill JW, Carlback M. 2011. Do brands matter? A comparison of branded and independent hotels' performance during a full economic cycle. International Journal of Hospitality Management. 30(3):515-521.

7. Damonte LT, Rompf PD, Domke DJ, Bahl R. 1997. Brand affiliation and property size effects on measures of performance in lodging properties. Hospitality Research Journal. 20(3):1-16.

8. Nikolskaya EY, Pasko OV, Volkova IA, Dekhtyar GM, Lebedeva OY. 2017. Boosting the competitiveness of hotel business operators in current conditions. Journal of Environmental Management and Tourism. 8(24):1629-1634.

9. Sheresheva MY, Oborin MS, Polyanskaya EE. 2018. International hotel chains in Russia the prospects and challenges of movement from megacities to smaller cities in Russian regions. Worldwide Hospitality and Tourism Themes. 10(4):421-435.

10. Andrade, Kaplan. 1998. How costly is financial (not economic) distress? Evidence from highly leveraged transactions that became distressed. Journal of finance. 53: 1443-1493.

11. Gilson S, John K, Lang L. 1990. Troubled debt restructuring: an empirical study of private reorganizations of firms in default. Journal of Financial Economics. 27: 315-353.

12. Pranowo K. 2010. Corporate financial distress perusahaan publik (non financial companies) di Indonesia [disertasi]. Bogor (ID): Institut Pertanian Bogor. 